\title{
Sex difference in choice of concealed or exposed refuge sites by preschool children viewing a model leopard in a playground simulation of antipredator behavior \\ Diferencias sexuales en la elección de sitios de refugio ocultos y expuestos por niños de preescolar viendo un modelo de leopardo en una simulación de juegos de comportamiento anti-depredador.
}

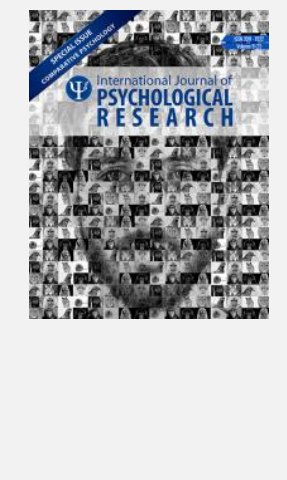

$\mathrm{R}$ e s e a r c h

Richard G. Coss ${ }^{\mathrm{a}} * \mathbf{\square}$ and Michael J. Penkunas ${ }^{\mathrm{a}}$

a Department of Psychology, University of California, Davis, USA.

ARTICLE INFO

\begin{abstract}
The current study of preschool children characterizes a semi-natural extension of experimental questions on how human ancestors evaded predation when encountering dangerous felids. In a pretend game on a playground, we presented full-size leopard and deer models to children $(N=39)$ in a repeatedmeasures experimental design. Prior to viewing the model presented $15-\mathrm{m}$ away, each child was instructed by the experimenter to go where she or he would feel safe. The rationale for this study was based on the anthropological construct of "sexual dinichism," positing that, during the Pliocene, smaller-bodied hominin females engaged in more arboreal behavior than larger-bodied males. Consistent with this construct, our previous simulation research using images of an African rock outcrop showed that, after viewing a lion, girls preferred a tree as refuge rather than a crevice or large boulder whereas boys did not differentiate these refuge sites. In this follow-up study, we predicted that, after viewing the model leopard, the preschool girls would differ from the boys by not choosing enclosed refuge sites analogous to the crevice. Analyses of a contingency table for the leopard model supported this hypothesis by yielding a significant interaction of sex and refuge location $(p=.031, d=.76)$, the source of which was a reliably larger percentage of girls not choosing concealed refuge $(p=.005, d=2.3)$. The interaction of sex and refuge location for the model deer was not significant $(p>.5)$. Our findings suggest that, in contrast to the deer, the girls selected exposed playground refuge sites rather than concealing ones to maintain visual contact with the leopard as a contingency for future action.
\end{abstract}

Article history:

Received: 19-04-2016

Revised: 01-06-2016

Accepted: 10-06-2016

Key words: preschool children, antipredator simulation, leopard recognition, refuge choice

\footnotetext{
* Corresponding author: Richard G. Coss, Department of Psychology, University of California, Davis, California, USA. Email address: rgcoss@ucdavis.edu
} 
R E S E A R C H

\begin{abstract}
RESUMEN
Este estudio de niños(as) en edad pre-escolar se caracteriza por ser una extensión semi-natural de los interrogantes experimentales sobre cómo los ancestros de los seres humanos evadieron la depredación al encontrarse con felinos peligrosos. En un juego simulado dentro de un parque infantil de juegos, presentamos modelos de tamaño natural de ciervos y leopardos $(N=39)$ con un diseño experimental de mediciones repetidas. Antes de que los(as) niños(as) vieran el modelo presentado a 15 metros de ellos(as), se les dijo que deberían ir adónde ella o él se sintiera seguro(a). La razón y lógica de este estudio se basó en la interpretación antropológica de la preferencia de cada sexo en la elección de habitats o nichos (sexual dinichism), la cual propone que durante el plioceno las hembras de los homínidos, de cuerpo más pequeño que los machos, tenían un comportamiento arborícola. Consistente con esta interpretación en nuestra previa simulación de investigación, en la cual utilizamos imágenes de un afloramiento rocoso en África en donde se veía a un león, las niñas prefirieron a un árbol como refugio en vez de una roca o una fisura en las rocas. Los niños no mostraron diferencias en la elección de esos refugios. En este estudio subsiguiente, habíamos predicho que después de ver el modelo del leopardo, las niñas diferirían de la elección hecha por los niños al no elegir sitios análogos a las fisuras en las rocas. El análisis de una tabla de contingencia para el modelo del leopardo respaldó esta hipótesis al mostrar una interacción significativa entre los sexos y el lugar del refugio $(p=.031, d=.76)$. Un fiable porcentaje mayor de las niñas no eligieron el refugio oculto $(p=.005, d=2.3)$. La interacción entre sexo y lugar de refugio para el modelo del ciervo, no fue significativa $(p<.5)$. Nuestros resultados sugieren que, en contraste con el modelo del ciervo, las niñas en vez de elegir refugios ocultos en el parque infantil de juegos seleccionaron refugios expuestos para mantener contacto visual con el leopardo como una contingencia para una acción futura.
\end{abstract}

\section{INTRODUCTION}

One of the strongest sources of natural selection in human evolution was the failure to cope effectively with dangerous circumstances. Avoidance of predators played a critical role in shaping the evolution of the human visual abilities to detect predators and in promoting the formation of social groups that shared communication during surveillance of potential danger (Barrett, 2005; Micheletta et al., 2012; Treves \& Palmqvist, 2007). Evidence of felid predation on eastern and southern African hominins is present in the fossil record (Brain, 1970; Leakey et al., 1995; Pickford \& Senut, 2001).

The current study of preschool children characterizes a semi-natural extension of experimental questions on how human ancestors evaded predation when surprised by sudden encounters with dangerous felids. The oldest member of our genus Homo in the late Pliocene of East Africa has an estimated age of 2.8 Myr (Villmoare et al., 2015). Older austrolopithecine
Palabras clave: niños preescolares, simulación antidepredador, reconocimiento leopardo, elección de regugio. 
R E S E A R C H

International Journal of Psychological Research

"sexual dinichism," to propose that male and female Au. afarensis "partitioned their time between the trees and ground differently. The heavy males spent less time in the trees than did females" (Susman et al., 1984, p. 149). A similar interpretation of sexual dinichism was adopted for common chimpanzees (P. t. versus) because smaller-bodied females forage for fruits in trees more effectively than much heavier-bodied males who are more likely to break thin branches (Doran, 1993).

With the emergence of Homo erectus who exhibited a more modern postcranial skeleton and less sexual dimophism than Au. afarensis (Plavcan et al., 2005), adaptations for routine tree climbing had already waned considerably. Nevertheless, modern humans still exhibit some morphological and behavioral relicts of historical sexual dinichism in arboreality that have persisted for a period of relaxed selection spanning at least 2 million years (Coss \& Goldthwaite, 1995; Coss \& Charles, 2004). For example, Qvindesland and Jónsson (1999) report that, as Icelandic girls approach puberty and experience hormonal effects on growth, $41 \%$ exhibit hypermobility of their peripheral joints and spine compared with only $13 \%$ of boys. In adults, young women have the ability to flex their feet with a chimpanzee-like plantarflexion useful historically for reaching branches while climbing trees and, unlike men, permits their dancing on pointe in ballet (Nigg et al., 1992; Russell et al., 2011).

There are several lines of evidence demonstrating that young children express action patterns reflecting relic sexual dinichism (see Coss \& Goldthwaite, 1995). For example, girls climb playground structures more frequently than boys and persist in their climbing to a later age than boys. Girls are also injured less frequently than boys while climbing on structures and they balance on balance beams with their arms out more than boys do in a T-like posture, demonstrating an inherent kinesthetic strategy for maintaining balance.

\subsection{Precocious expression of antipredator behavior}

Precocious antipredator behavior expressed by young animals is evident in Thomson's gazelles (Eudorcas thomsonii) fawns that, when hidden in tall grass from view of predators, will stot into view when they jump up repeatedly (Caro, 1986; Fitzgibbon, 1990). Similarly, California ground squirrel pups (Otospermophilus beecheyi) that are targets of snake predation will investigate snakes in a manner more appropriate for larger, less vulnerable adults (Putman et al., 2015). This innate ability to recognize snakes as

\section{Sex difference in refuge choice}

predators persists even in ground squirrels living in environments where snakes have been rare or absent for 300,000 years (Coss, 1991a,b). This trait endures under relaxed selection because gene expression shaping the neural circuitry subserving these defensive action patterns occurs during the early stages of neuronal outgrowth. Moreover, these neural circuits maintain their functionality despite later remodeling of neurons as an "experience-dependent" developmental process (see Black \& Greenough, 1986) or when neuron growth is arrested by severe experiential deprivation in captivity (Tromborg \& Coss, 2015). As such, this robustness in early neural-circuit installation and maintenance later in life allows these circuits to await the stochastic circumstance of activating appropriate antipredator behavior when needed and, in some cases, after thousands of years of relaxed selection (Lahti et al., 2009).

Early hominins likely experienced a long history of nighttime predation in sleeping trees, not unlike that experienced by nonhuman primates that select the edges of crown canopies to escape predators and for sleeping at night (Isbell, 1994; Busse 1980; Ramakrishnan \& Coss, 2001 a,b). In humans, recognition that a large-bodied felid is potentially dangerous was evident in preschool-aged British children who ranked a lion figurine as constituting the greatest danger in a three-dimensional diorama displaying a variety of dangerous situations (Penkunas et al., 2014). Young American children also exhibited the precocious ability to detect a lion quickly in visual arrays of computer images of antelope and this ability does not differ appreciably from Indian children living in forests where leopards and tigers are present (cf. Penkunas \& Coss, 2013 a,b; Yorzinski et al., 2014).

Preschool children often imagine the presence of "scary things" near their beds at night. In an experimental study by Coss and Goldthwaite (1995), a larger percentage of preschool girls and adult women reflecting on their childhood nighttime fears reported that their "scary thing" lurked below their beds in contrast with a larger percentage of preschool boys and adult men who reported that their scary thing lurked from the side locations relative to their beds. This precocious awareness of the spatial location of something dangerous in preschool girls may reflect the historical vantage point of assessing nighttime threats by Pliocene hominins sleeping aloft in trees. Similar assessment of potential threats lurking below is evident in nonhuman primates that select sleeping sites in trees to evade nighttime predation (Koops et al., 2012; Pruetz et al., 2008; Ramakrishnan \& Coss, 2001a,b). Consistent with the sexual dinichism hypothesis, a larger percentage of boys expressed greater 
R E S E A R C H

International Journal of Psychological Research

fearfulness of something that could approach them from the side while sleeping arguably characterizes historical nighttime refuge at ground level.

In light of this theoretical perspective, Coss and Moore (2002) addressed the question of whether preschool children would show evidence of relic sexual dinichism in landscape perception, especially the functional utility (Gibsonian affordances, see Gibson, 1986) of trees as antipredator refuge sites. Coss and Moore (2002) presented 4 to 6 year-old Israeli children with a sequence of computer-generated images showing various views of an African rock outcrop. This virtual tour explored a crevice between two boulders, top of a large boulder, and the crown canopy of an adjacent acacia tree. After viewing the image of a male lion and its appearance from of each of the three refuges, the children were asked to point to the place they would feel safe from the lion. A reliably larger percentage of girls selected the acacia tree to climb as compared with the percentages selecting the crevice and boulder. The pattern of choice differed for boys, with the largest percentage selecting the crevice as a safe refuge, but this percentage was not reliably larger than the percentages selecting the boulder and tree. In an associated study, 3 to 4 year-old American children without tree-climbing experience were shown silhouettes of four trees with narrow or wide crown canopies and were asked where they would go in the trees to feel safe from a lion. Girls differed reliably from boys by pointing to safe places near the edge of the crowns in the trees with wide crown canopies. Baboons, macaques, and Hanuman langurs behave similarly after being surprised by a leopard or when chased into trees, selecting the thinner branches near the edge of crown canopies to escape or in anticipation of predatory attacks at night (Busse, 1980; Ramakrishnan \& Coss, 2001a). It seems reasonable to argue that, along with other nonhuman primates, human children appear to have a precocious understanding that the edge of the crown canopy consists of thin, low weight-bearing branches that preclude access by heavy-bodied arboreal predators. Climbing trees typically begins around 6 years of age in hunter-gatherers, and Batek children of Malaysia are effective climbers who can move quickly through the canopy (Kraft et al. 2014, p. 197).

\subsection{Experimental questions and predictions}

A semi-natural playground setting was used to test the hypothesis that preschool children would exhibit a sex difference in their choices of refuge sites after seeing a model leopard. As such, several facets of our study provided continuity with the
Sex difference in refuge choice

aforementioned research on preschool children who selected safe places after viewing an image of a lion following a virtual tour of an African rock outcrop (Coss \& Moore, 2002). Although playgrounds do not engender the full diversity of refuge present in natural settings (Fjørtoft, 2001), they are often equipped with structures analogous to those used in natural settings for hiding and climbing. The playground selected as the experimental setting consisted of variety of vegetated areas and relatively novel structures for climbing and hiding designed to enhance children's play experiences (see Cosco et al., 2010 for discussion of this type of playground design). For our study, we selected two categories of refuge (concealed or exposed) provided by vegetation and playground structures selected by the preschool children who participated in our study. Based on the findings of Coss and Moore (2002) and prompted by the theory of sexual dinichism in hominin ancestors, we hypothesized that boys and girls would differ in selecting safe places after viewing a realistic two-dimensional leopard model. Tree climbing for concealment was unavailable to the children because the low branches of playground trees had been trimmed. Nevertheless, enclosed and climbable playground structures were available that might engender a sex difference in refuge-seeking preference. If analogous to the aforementioned computer-generated simulation in which girls preferred to climb a tree rather than hiding in a crevice after viewing a lion (Coss \& Moore, 2002), we predicted that, after viewing a model leopard, the preschool girls in our study would differ from the preschool boys by not choosing enclosed playground structures that afforded concealment as safe refuge.

\section{METHOD}

\subsection{Participants}

The current study was conducted on a playground at the Center for Family and Child Studies at the University of California, Davis campus. Typically developing child participants were 25 boys (mean age: 54.0 months, $\mathrm{SD}=7.8$, range $=40-64$ months) and 14 girls (mean age: 55.1 months. $\mathrm{SD}=7.8$, range $=40-67$ months) who provided parental approval under human subjects IRB number 2008-16272-2. The study was conducted over a two-month period on two consecutive years while no children other than the participant were on the playground.

\subsection{Study Site}

The playground setting at the Center for Family and Child Studies was designed to maximize children's 
R E S E A R C H

outdoor experiences by providing a large area $(67 \mathrm{~m} \times$ 27-31 m) with low hills and diverse playground equipment distributed broadly throughout the playground. Ground-level vegetation and structures used by children to conceal themselves while hiding were: 4 trees with wide trunks, 2 large tunnels (Figure 1), a simulated boat cabin, a small wooden enclosure, a cement climbing structure to hide inside or behind, the dark underside of slide stairs for crouching inside, a small table for crouching behind, and trash can for crouching behind. Nine small trees with narrow trunks, and a row of bamboo against a fence were available for hiding behind, but provided little concealment. Playground structures climbed upon by participating children were: a slide platform with stairs, a large metalframed structure, a wheeled platform with overhead bar, and inverted U-shaped bar, and a cement structure with toeholds and handholds for climbing.

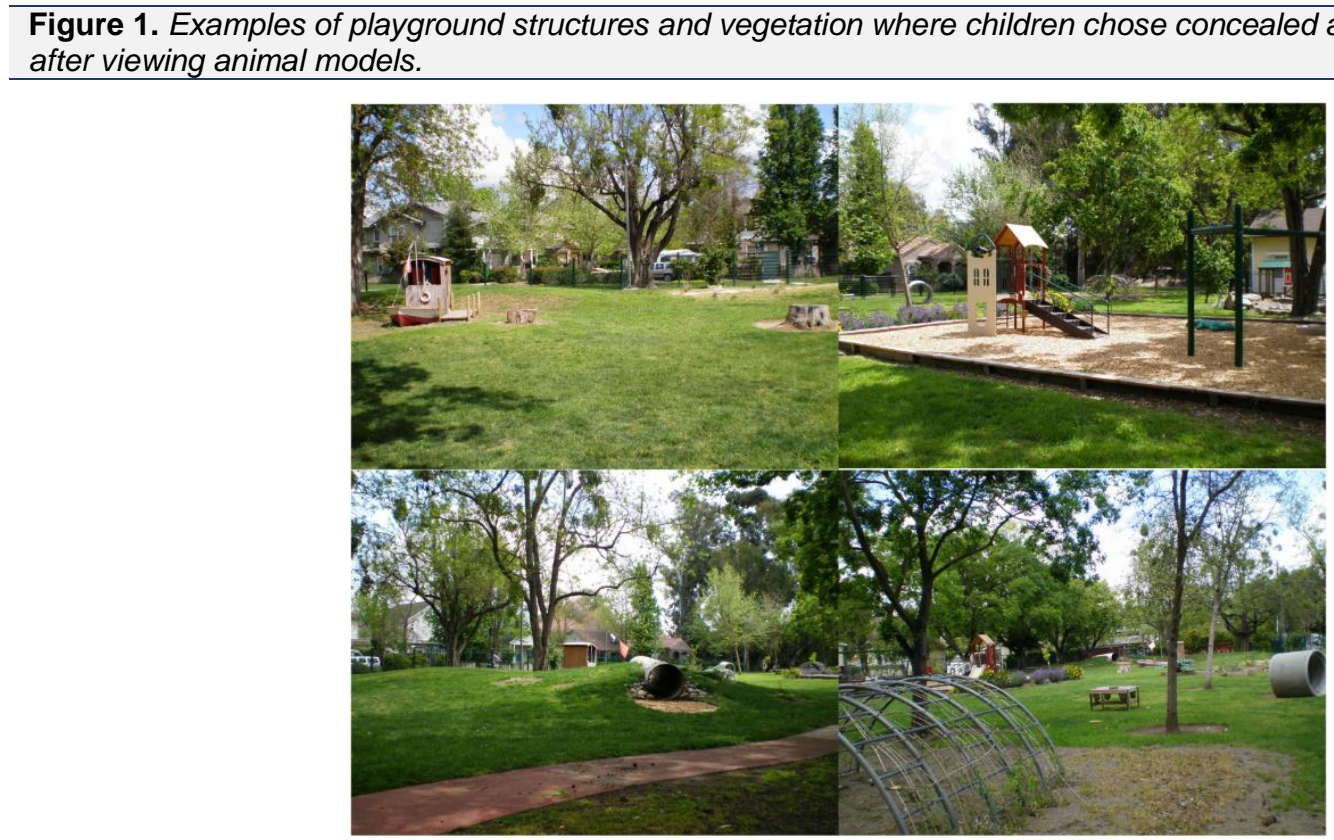

\subsection{Animal models}

A model leopard (Panthera pardus) and a model female mule deer (Odocoileus hemionus hemionus) were presented to children to examine how they responded to the sudden appearance of an animal that could be perceived as dangerous. These models were used in previous research on the antipredator behavior of Columbian black-tailed deer (O. h. columbianus; see Figure 1 in Stankowich \& Coss, 2007). The leopard and deer models constructed of lifesized photographs were scaled to have approximately the same total surface area and similar body lengths $(1.5 \mathrm{~m})$. These photographic models were printed and mounted on foam board with a flexible hinge in the center used to fold the models for transport and to conceal them behind objects prior to presentations.

\subsection{Model-presentation procedure}

Prior to retrieving the child from the classroom for a trial, the experimenter (MJP) positioned a Bell bicycle helmet on the child's head. The helmet was equipped with a small video camera (Oregon Scientific model ATC2K with a narrow $54^{\circ}$ field of view) containing a microphone. The child was presented with each of the animal models one to two weeks apart from one of two playground locations from a 15-m distance in a balanced randomized order. Model-viewing location 1 was on the cement patio with the model hidden from view by an assistant behind a large stump. On cue, the assistant positioned the model at the side of the stump (see Figure 2). Model-viewing location 2 was on top of a small grassy mound and the model was positioned into view next to a wide tree trunk. To start the trial, the experimenter described the following scenario: "Let's play a game of pretend. We are going to pretend that an animal has escaped from the zoo and was seen nearby. When you see the animal, I want you to go where you would feel safe. Now here is the animal!" On this cue, the model animal was quickly unfolded and positioned into view. A tripod-mounted digital video camera (Panasonic model PV-DV601D with a $20 \times$ zoom lens) recorded the entire trial as the 
R E S E A R C H

child walked or ran to the location where she or he felt safe. The helmet-mounted video camera insured that the entire sequence of finding a safe place was recorded because children occasionally ran behind objects blocking the view of the tripod-mounted camera. Another benefit of the helmet-mounted video camera was the ability to quantify the children's head positions while they moved to safe places and to record what the child said after being debriefed at the end of the trial.

Figure 2. Children running to refuge after viewing a model leopard $(A)$ and model mule deer $(B)$.

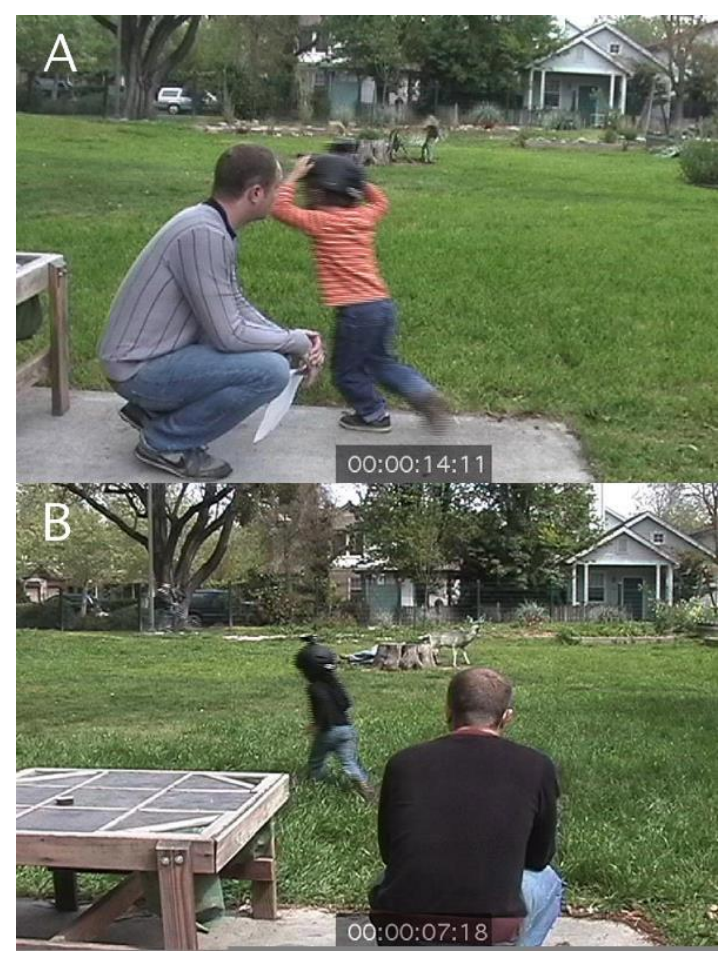

\subsection{Behavioral measures}

After being instructed to find a place to feel safe after viewing the leopard and deer models, the children walked or ran to vegetation or structures that afforded two refuge categories (concealed or exposed), yielding a $2 \times 2$ (sex and refuge category) contingency table for each model. The concealed category consisted of playground locations selected by the children in which the children could hide their bodies completely out from view. In several trials, children peeked around or over the edge of occluding structures to look at the models. Despite exposure of parts of their faces, these trials were classified as concealed. The exposed category consisted of children walking or running into the open and stopping, or stopping after they reached vegetation and playground structures where their bodies were not concealed from view.

The latency to seek refuge away from the experimenter might be indicative of how the child evaluated model dangerousness and selected appropriate playground structures or vegetation to feel safe. This measure has been useful in other studies of predator-model discrimination (e.g., Coss \& Ramakrishnan, 2000). A related measure influenced by children's hesitancy was the number of prompts, such as "go find a safe place!" and "OK, go!" made by the experimenter to encourage hesitant children to seek refuge.

The helmet-mounted video cameras yielded information about head position as children moved away from the experimenter. As such, the child's head position while moving provided a proxy measure of the child's visual targeting of their chosen refuge site. In several trials, the children moved in a large arc to enter a tunnel or to circumvent a structure that blocked their view of their target. Since side-to-side head motion did not occur, this arc of movement was treated as a single bout of visual fixation toward the targeted refuge. The frequency of head turning as children moved was examined independently and in the context of travel time (sec) and distance covered using a scaled aerial view of the playground obtained from Google Maps.

\section{RESULTS}

\subsection{Qualitative analyses}

All the children appeared eager to participate in the pretend game, with none declining participation prior to model presentation. Once a model was positioned into view, children facing the experimenter were requested to turn and look at the model. Examples of children running after being prompted the first time to leave appear in Figure 2. Other than hesitancy of some children to leave the experimenter immediately, none of the children expressed fear while they looked at the models. For both model-viewing locations, the children selected refuge at distances ranging from 4- to 30-m distance from the experimenter As described below in greater detail, once the children started moving away, they maintained a relatively consistent linear path to their chosen locations. While running from the leopard in one trial, 1 boy yelped repeatedly like a nonhuman primate giving an alarm call from its arboreal refuge site (for review, see Isbell, 1994). We were surprised that both boys and girls chose the long tunnel for concealment from the deer, but for the leopard, only 2 girls entered this tunnel. 
Climbing structures were not the primary choice of safe places as only 4 children climbed them. Two girls selected the trunks of trees as safe places, the largest of which was hidden behind. Only 1 boy climbed the cement structure with hand and footholds. Most children quickly returned to the starting location after selecting their "safe place" where the experimented requested information about their location, such as: "Where did you go to feel safe?" and "So why was that a good place to feel safe?" Some children pointed to the places they selected rather than describe them. Audible over wind or background noise, 24 children spoke coherently, with $58.3 \%$ providing answers using the word "hide" or words contextually suggestive of hiding when they stated that they could not see the animals or the animals could not see them.

\subsection{Quantitative analyses}

\subsubsection{Choice of concealment or exposure}

One boy repeatedly used the experimenter to hide behind and another boy walked towards the models so both were excluded from this analysis. A contingency table was constructed for the leopard model consisting of 11 boys and 2 girls who selected concealed locations and 12 boys and 12 girls who selected exposed locations. The tunnel was the concealed location for the two girls. Multinomial loglinear analysis with maximum likelihood estimation revealed that the interaction of frequencies for sex and refuge category was statistically significant $(\mathrm{N}=37$, Log linear $x^{2}=4.648 ; \mathrm{df}=1 ; \mathrm{p}=.031$ and a medium effect size, Cohen's $d=.76$, Figure 3 ). Data partitioning (Agresti, 2002, p. 82) revealed that the source of this interaction was the large frequency (Figure 3 ) of girls who selected exposed refuge locations $(n=14$; Log linear $\mathrm{x} 2=7.925, \mathrm{df}=1, \mathrm{p}=.005$ and a large effect size, Cohen's $d=2.3$ ). A contingency table for the deer model consisted of 9 boys and 5 girls who selected concealed locations and 14 boys and 9 girls who selected exposed locations. The interaction of sex and refuge category for the deer model was not significant $\left(\mathrm{N}=37\right.$; Log linear $\left.\mathrm{X}^{2}=.043 ; \mathrm{df}=1 ; \mathrm{p}>.5\right)$. After viewing both models, $35.7 \%$ of girls and $33.3 \%$ of boys switched concealed or exposed refuge categories.

\subsubsection{Latency to leave the experimenter and rompting}

Thirty-nine children selected a refuge site, including the child who stood behind the experimenter for both models. After their initial instruction to find a safe place after viewing the models, the children varied considerably in their willingness to leave the experimenter. Regression analysis examined the association of latency (sec) to leave the experimenter after his initial prompt and the number of prompts given to initiate leaving. Since the child's hesitancy to leave influenced prompting and prompting influenced leaving, there was a two-way causal association between latency and prompting. With latency as the predictor variable, these regressions yielded large correlation coefficients for both models (leopard: $r=.577$; deer: $r=$ $.717 ; \mathrm{df}=37 ; p<.0005)$. With latency examined as the dependent variable rather than the independent variable, a one-factor between subjects (sex), onefactor within subjects (2 models) repeated measures analysis of variance (ANOVA) was employed to compare mean differences for sex and models. Although the latency to leave the experimenter was longer for the leopard (mean $=6.4 \mathrm{sec}$ ) compared with the deer (mean $=5.3 \mathrm{sec})$, the main effects for $\operatorname{sex}(p=$ $.60)$ and models $(p=.38)$ and the interaction of sex and models $(p=.87)$ were not significant.

Figure 3. Percentage of children selecting concealed and exposed refuge sites after viewing a model leopard.

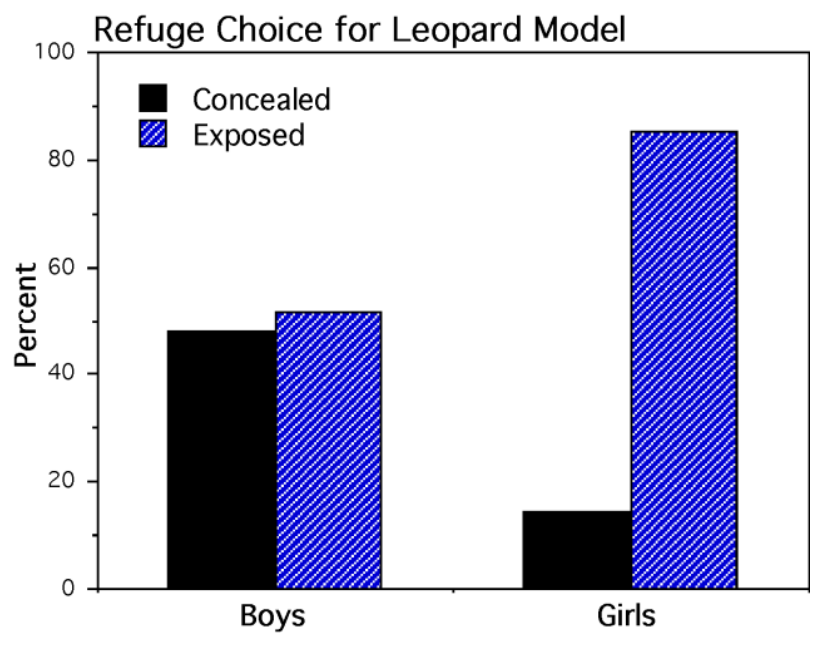

When the number of prompts was used as the dependent variable, a two-way repeated-measures ANOVA revealed a significant main effect, averaged for sex, for the animal models $(F=5.679$; $d f=1,37$;

$p=.022$ with a large effect size, Cohen's $d=.8$ ). As shown in Figure 4, the leopard model engendered an average of 1.56 prompts $(95 \% \mathrm{Cl}=1.08$ to 2.0$)$ while the deer model engendered an average of 1.08 prompts $(95 \% \mathrm{Cl}=0.64$ to 1.52$)$. Follow-up regression analysis with age as the predictor variable revealed a significant association in which younger children required more prompting than older children for the deer model $(r=-.323 ; \mathrm{df}=37 ; \mathrm{p}=.045)$. The leopard 
R E S E A R C H

International Journal of Psychological Research

model showed a nonsignificant trend in the same direction $(r=-.271 ; \mathrm{df}=37 ; \mathrm{p}=.095)$.

Figure 4. Number of prompts from the experimenter to elicit refuge seeking. Means and standard errors values are shown.

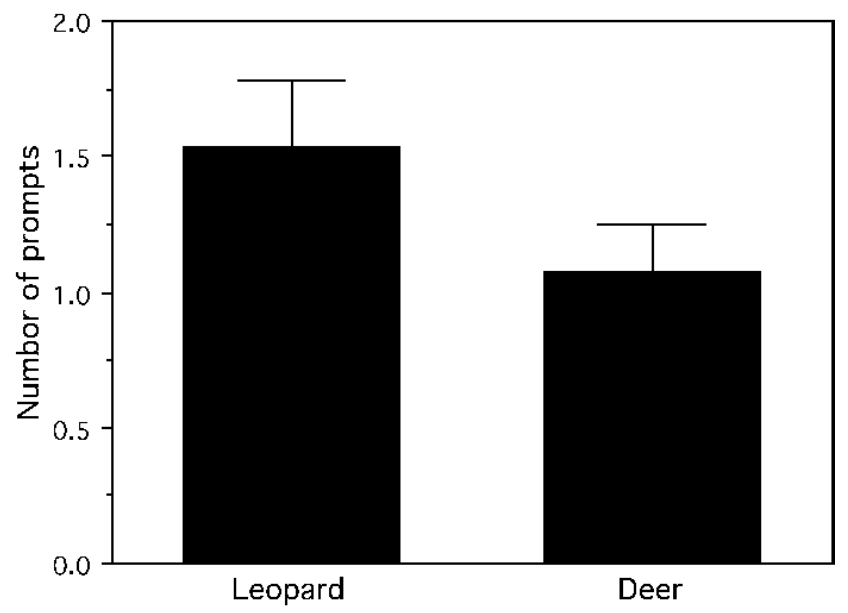

\subsubsection{Head turning while seeking a safe place}

Helmet-mounted video recordings providing proxy information on shifts of visual attention as children walked or ran toward their selected refuge. Due to excessive image vibrations as children ran, our confidence in measuring accurate head turning was restricted to 19 boys and 14 girls. A mixed repeated measures ANOVA failed to show any significant main effects for sex $(p=.185)$ and models $(p=.764)$ or the interaction of sex and models $(p=.516)$. Nevertheless, this small difference in head-turning bouts for boys (mean $=1.79$ ) and girls (mean $=2.29$ ) suggests that, once children had made their choice of a safe place, their attention on their choice of a safe place while walking or running was maintained.

\section{DISCUSSION}

The current study employed a pretend game on a preschool playground to simulate the historical condition in which a young child accompanied by an adult detected a dangerous animal and was told by the adult to find a safe place. The core hypothesis of relic sexual dinichism (Coss \& Charles, 2004) was used to develop an ancillary hypothesis of sex difference in refuge-seeking behavior after viewing a model leopard. The absence of trees with low-hanging branches on the playground precluded testing a sex difference in tree climbing. However, the enclosed playground structures

\section{Sex difference in refuge choice}

affording concealment were analogous to the crevice not chosen by Israeli preschool girls as a safe place after viewing a lion in the virtual tour of an African rock outcrop (Coss \& Moore, 2002). As such, we predicted that preschool girls would differ from preschool boys by avoiding enclosed structures after viewing the model leopard. Our results provided support for this hypothesis because a reliably smaller percentage of girls selected enclosed refuge sites that afforded concealment from the leopard, generating the statistically significant interaction of sex and refuge category. It is important to emphasize that there was no interaction of sex and refuge category after children viewed the model deer.

\subsection{Sex difference in spatial abilities}

Our finding that girls did not choose concealed playground areas when seeking refuge from the leopard suggest that the girls and boys differed in their assessments of safety afforded by their refuge choices and vulnerability to the animals represented by the models. By remaining exposed rather than hiding in a fixed location, the girls would have had more flexible options of altering their choices of safe places while continuing to monitor the leopard. As revealed by the helmet video cameras after children had arrived at their safe places in exposed locations, this contingency for appraising future action by additional scanning was evident in the marked increase in lateral head movements of both girls and boys. This form of cognitive assessment might have been useful in the past especially for Pliocene hominin females who were more vulnerable than males due to their smaller body size.

A number of studies of sex difference in spatial abilities conducted with an evolutionary perspective have been based on the hunter-gatherer theory that men needed to employ different navigational skills for hunting in unfamiliar terrain than women whose gathering activity would have involved less ranging from campsites (cf. Silverman \& Choi, 2007; Dabbs et al., 1998; Postma et al., 2004). Indeed, research shows that women rely predominantly on distal landmark cues while men rely on both landmark and geometric information (e.g., Sandstrom et al., 1998). More relevant to our study, Ecuyer-Dab and Roberts (2004) argue that, under threatening conditions such as encounters with a predator, a broad range of mammalian females might differ from their male counterparts by using an "attentional style" that focuses on spotting "fast retreat paths." In our previous research on leopard recognition and flight behavior in nonhuman primates, we have not observed a sex difference in 
R E S E A R C H

International Journal of Psychological Research

patterns of flight behavior. After spotting a model leopard like the one used in our current experiment, both male and female bonnet macaques (Macaca radiata) immediately turned away and ran to the nearest trees (Coss \& Ramakrishnan, 2000). It is evident from this research that trees became the most important landmarks for orienting and guiding flight behavior for both sexes.

\subsection{Hesitation to leave the experimenter and group protection}

Compared with the model deer, the model leopard engendered a reliably larger number of prompts to find a safe place. Despite the calm demeanor of the experimenter as he encouraged the children to seek refuge, the ensuing hesitation of younger children to leave the experimenter as a presumed source of safety or protection, suggests that the children perceived the leopard as more potentially dangerous than the deer. This is a realistic reflection of behavior that could unfold during sudden encounters with large felid predators, especially when a child is not in close proximity to a group (Coss et al. 2009; Treves \& Naughton-Treves, 1999). In the rare situations in which pumas (Puma concolor) attack humans in North American wilderness, they are more likely to inflict serious injury or death when individuals are hiking apart from their groups. Children separated from adults are at a particular risk of attack. In our current study, both the experimenter and his assistant constituted a small group, and it seems reasonable to argue that the youngest children felt safe after stopping several meters away; as mentioned above, one child selected the back of the experimenter as his refuge site.

In the first volume of his seminal book on children's attachment behavior in strange situations, John Bowlby (1982) presented an ethological perspective of how children might seek refuge from danger as one source for the development of attachment behavior. He states: "All in all, it is held, of the various suggestions advanced for the function of attachment behaviour, protection from predators seems by far the most likely" (p. 191 second edition).

Human groups can achieve protection from predators by standing their ground and even mobbing them. Moreover, children in a group can be quite bold when confronted with a predator. In the forest of southern India, a group of 5 to 9 year-old girls quickly gathered around a leopard that had seized one of the girls and hit it repeatedly with sticks until the leopard dropped the girl and fled (Coss et al., 2009).

Under the rare incidences in zoological parks when large animals do escape their enclosures,

\section{Sex difference in refuge choice}

triggering animal-escape procedures, adults are instructed by staff to usher children to safe areas; albeit, retreating and hiding in a protected area was reported in one incident when the escaped animal, a large tapir, ran toward a father with his two children (Spiteri, 2010). Emergency evacuations are another context for parentchild interactions analogous to our experimental protocol of telling the child to leave an adult. For example after the 2016 terrorist bombing of the Brussels airport, the initial version of breaking news from the New York Times (March 23, 2016) reported an interview with an injured mother who shouted "run" to her son who refused to leave her side. This is not unusual in emergency situations. Despite instructions from adults, children stressed by an emergency evacuation can panic and fail to flee from dangerous situations (Gaines et al., 2004).

\subsection{Social influences on animal perception}

With respect to the evocative properties of the leopard model, there are several contexts in which young children might observe large felid predators exhibiting dangerous behaviors, such as television programs showing lions, leopards, and cheetahs hunting prey (Penkunas \& Coss, 2013a). This type of programming has increased in recent years, notably BBC nature programs designed to capture the interest of adult viewers (personal communication from Bernard Walton, BBC producer, 1990). Close-up viewing of large cats in zoological parks would be another situation where children might hear adult discussions of animal dangerousness. On the other hand, deer and similarly appearing antelope are less likely to engender provocative comments.

In sum, our study showed that preschool girls differed from same-age boys in their choice of a refuge that was not concealed after viewing a model leopard, but not a model deer. This result suggests that the girls engaged in deliberate evaluation of the simulated risk rather than hiding in a location that would cause them to lose the ability to gather information that could guide further actions. Our simulation of an historical antipredator context for evaluating a sex difference in threat assessment by young children adds additional insight into theoretical arguments about the precocious expression of adult-like risk assessment and the presence of behavioral relicts persisting under prolonged relaxed selection.

\section{ACKNOWLEDGMENTS}

This research was supported by the University of California, Davis, Summer Session Research Funds 
R E S E A R C H

International Journal of Psychological Research

to R. G. Coss. The authors acknowledge the cooperation of the families, faculty, and staff of the Center for Child and Family Studies in the Department of Human and Community Development at the University of California, Davis in conducting this study. We also thank Dilyara Dzhabbarova, Taylor Ely, and Denny Wu for assistance in video recording children and quantification to video action.

\section{REFERENCES}

Agresti, A. (2002). Categorical data analysis. Second Edition. New York: Wiley.

Barrett, H. C. (2005). Adaptations to predators and prey. In D. Buss (Ed.), The handbook of evolutionary psychology (200-223). Hoboken, NJ: Wiley.

Black, J. E., \& Greenough, W. T. (1986). Induction of pattern in neural structure by experience: implications for cognitive development (1-50). In M. E. Lamb, A. L., Brown \& B. Rogoff B (Eds.) Advances in developmental psychology, Vol 4. New Jersey: ErlbaumHillsdale.

Bowlby, J. (1982). Attachment and loss. Vol. 1. Attachment. Second edition. New York: Basic Books.

Brain, C. K. (1970). New finds at the Swartkrans australopithecine site. Nature (London), 225, 1112-1119.

Busse, C. (1980). Leopard and lion predation upon chacma baboons living in the Moremi Wildlife Reserve. Botswana Notes \& Records, 12, 1521.

Caro, T. M. (1986). The functions of stotting in Thomson's gazelles: Some tests of the predictions. Animal Behaviour, 34, 663-684.

Cosco, N. G., Moore, R. C., \& Islam, M. Z.. (2010). Behavior mapping: A method for linking preschool physical activity and outdoor design. Medicine \& Science in Sports \& Exercise, 42, 513-519.

Coss, R. G. (1991a). Context and animal behavior: 3 . The relationship between early development and evolutionary persistence of ground squirrel antisnake behavior. Ecological Psychology, 3, 277-315.

Coss, R. G. (1991b). Evolutionary persistence of memory-like processes. Concepts in Neuroscience, 2, 129-168.

Coss, R. G., \& Charles, E. P. (2004). The role of evolutionary hypotheses in psychological research: Instincts, affordances, and relic sex

\section{Sex difference in refuge choice}

differences. Ecological Psychology, 16, 199236.

Coss, R. G., Fitzhugh, E. L., Schmid-Holmes, S., Kenyon, M. W., \& Etling, K. (2009). The effects of human age, group composition, and behavior on the likelihood of being injured by attacking pumas. Anthrozoös, 22, 77-87.

Coss, R. G., \& Goldthwaite, R. O. (1995). The persistence of old designs for perception. In N. $\mathrm{S}$. Thompson (Ed.), Perspectives in ethology, Vol. 11. Behavioral design (83-148). New York: Plenum.

Coss, R. G., \& Moore, M. (2002). Precocious knowledge of trees as antipredator refuge in preschool children: An examination of aesthetics, attributive judgments and relic sexual dinichism. Ecological Psychology, 14, 181-222.

Coss, R. G., \& Ramakrishnan, U. (2000). Perceptual aspects of leopard recognition by wild bonnet macaques (Macaca radiata). Behaviour, 137, 315-335.

Dabbs, J. M. Jr., Chang, E-L., Strong, R. A., \& Milun, R. (1998). Spatial ability, navigation strategy, and geographic knowledge among men and women. Evolution and Human Behavior, 19, 89-98.

Doran, D. M. (1993). Sex differences in adult chimpanzee positional behavior: The influence of body size on locomotion and posture. American Journal of Physical Anthropology, 91, 99-115.

Ecuyer-Dab, I., \& Robert, M. (2004). Have sex differences in spatial ability evolved from male competition for mating and female concern for survival? Cognition, 91, 221-257.

Fitzgibbon, C. D. (1990). Anti-predator strategies of immature Thomson's gazelles: Hiding and the prone response. Animal Behaviour, 40, 846855.

Fjørtoft I. (2001). The natural environment as a playground for children: The impact of outdoor play activities in pre-primary school children. Early Childhood Education Journal, 29, 111119.

Gaines, S. K., \& Leary, J. M. (2004). Public health emergency preparedness in the setting of child care. Family \& Community Health, 27, 260265.

Gibson, J. J. (1986). The ecological approach to visual perception. Hillsdale, New Jersey: Lawrence Erlbaum Associates, Inc. (Original work published 1979). 
Isbell, L. A. (1994). Predation on primates: Ecological patterns and evolutionary consequences. Evolutionary Anthropology, 3, 61-71.

Kappelman, J., Ketcham, R. A., Pearce, S., Todd, L., Akins, W.,Colbert, M. W., Feseha, M., Maisano, J. A., \& Witzel, A. (2016). Perimortem fractures in Lucy suggests mortality from fall out of tall tree. Nature, doi:10.1038/nature 19332.

Koops, K., McGrew, W. C., \& Vries, H., \& Tetsuro Matsuzawa, T. (2012). Nest-building by chimpanzees (Pan troglodytes verus) at Seringbara, Nimba mountains: Antipredation, thermoregulation, and antivector hypotheses. International Journal of Primatology, 33, 356380.

Kraft, T. S., Venkataraman, V. V., \& Dominy, N. J. (2014). A natural history of human tree climbing. Journal of Human Evolution, 71, 105118.

Lahti, D. C., Johnson, N. A., Ajie, B. C., Otto, S. P., Hendry, A. P., Blumstein, D. T., Coss, R. G., Donohue, K., \& Foster, S. A. (2009). Relaxed selection in the wild: Contexts and consequences. Trends in Ecology and Evolution, 24, 487-496.

Leakey, M. G., Feibel, C. S., McDougall, I., \& Walker, A. (1995). New four-million-year-old hominid species from Kanapoi and Allia Bay, Kenya. Nature (London), 376, 565-571.

Micheletta, J., Waller, B. M., Panggur, M. R., Neumann, C., Duboscq, J., Agil, M., \& Engelhardt, A. (2012). Social bonds affect anti-predator behavior in a tolerant species of macaque, Macaca nigra. Proceedings of the Royal Society Series B. doi:10.1098/rspb.2012.1470.

Nigg, B.M., Fisher,V., Allinger, T. L., Ronsky, J. R.,\& Engsberg, J. R. (1992). Range of motion of the foot as a function of age. Foot and Ankle, 13, 336-343.

Penkunas, M. J., \& Coss, R. G. (2013a). Rapid detection of visually provocative animals by preschool children and adults. Journal of Experimental Child Psychology, 114, 527-536.

Penkunas, M. J., and Coss, R. G. (2013b). A comparison of rural and urban Indian children's visual detection of threatening and nonthreatening animals. Developmental Science, $\quad 16, \quad 463-475 . \quad$ DOI: 10.1111/desc. 12043.

Penkunas, M. J., Coss, R. G., \& Shultz, S. (2014). Risk assessment by British children and adults. International Journal of Psychological Studies, 6, 32-43.
Pickford, M., \& Senut, B. (2001). The geological and faunal context of Late Miocene hominid remains from Lukeino, Kenya. Comptes Rendus de l'Académie des Sciences lla: Earth and Planetary Science, 332, 145-152.

Plavcan, J. M., Lockwood, C. A., Kimbel, W. H., Lague, M. R., \& Harmon, E. H. (2005). Sexual dimorphism in Australopithecus afarensis revisited: How strong is the case for a humanlike pattern of dimorphism? Journal of Human Evolution, 48, 313-320.

Postma, A., Jager, G., Kessels, R. P. C., Koppeschaar, H. P. F., \& van Honk, J. (2004). Sex differences for selective forms of spatial memory. Brain and Cognition, 54, 24-34.

Pruetz, J. D., Fulton, S. J., Marchant, L. F., McGrew, W. C., Schiel, M., \& Waller M. (2008). Arboreal nesting as anti-predator adaptation by savanna chimpanzees (Pan troglodytes verus) in southeastern Senegal American Journal of Primatology, 70, 393-401.

Putman, B.J., Coss, R. G \& Clark, R. W. (2015). The ontogeny of antidepredator behavior: age differences in California groud squirrels (Otospermophilus beecheyi) at multiple stages of rattlesnake encounters. Behav Ecol Sociobiol, 69, 1447. doi:10.1007/s00265-0151957-2

Qvindesland, A., \& Jónsson, H. (1999). Articular hypermobility in Icelandic 12-year-olds. Rheumatology, 38, 1014-1016.

Ramakrishnan, U., \& Coss, R. G. (2001a). Strategies used by Bonnet Macaques (Macaca radiata) to reduce predation risk while sleeping. Primates, 42, 193-206.

Ramakrishnan, U., \& Coss, R. G. (2001b). A comparison of the sleeping behavior of three sympatric primates: A preliminary report. Folia Primatologica, 72, 51-53.

Russell, J. A., Shave, R. M., Kruse, D. W. Koutedakis, Y., \& Wyon, M. A. (2011). Ankle and foot contributions to extreme plantar- and dorsiflexion in female ballet dancers. Foot \& Ankle International, 32, 183-188.

Sandstrom, N. J., Kaufman, J., \& Huettel, S. A. (1998). Males and females use different distal cues in a virtual environment navigation task. Cognitive Brain Research, 6, 351-360.

Silverman, I., \& Choi, J. (2007). The hunter-gatherer theory of sex differences in spatial abilities: Data from 40 countries. Archives of Sexual Behavior, 36, 261-268.

Spiteri, R. (2010). Escaped animal scares family. Niagara Falls Review, July 26. 
International Journal of Psychological Research

http://www.niagarafallsreview.ca/2010/07/26/e scaped-animal-scares-family.

Stankowich, T., \& Coss, R. G. (2007). The reemergence of felid camouflage with the decay of predator recognition in deer under relaxed selection. Proceedings of the Royal Society, Series B, 274, 175-182.

Stern, J. T., Jr., \& Susman, R. L. (1983). The locomotor anatomy of Australopithecus afarensis. American Journal of Physical Anthropology, 60, 279-317.

Susman, R. L., Stern, J. T., Jr., \& Jungers, W. L. (1984). Arboreality and bipedality in the Hadar hominids. Folia Primatologica, 43, 113-156.

Treves A., \& Naughton-Treves, L. (1999). Risk and opportunity for humans coexisting with large carnivores. Journal of Human Evolution, 36, 275-282.

Treves, A., \& Palmqvist, P. (2007). Reconstructing Hominin Interactions with Mammalian

\section{Sex difference in refuge choice}

Carnivores (6.0-1.8 Ma). In S. Gursky-Doyen, \& K. A. I. Nekaris (Eds.), Primate anti-predator strategies (355-381). New York: Springer Science \& Business Media LLC.

Tromborg, C. T., \& Coss, R. G. (2015). Isolation rearing reveals latent antisnake behavior in California ground squirrels (Otospermophilus becheeyi) searching for predatory threats. Animal Cognition, 18, 855-865.

Villmoare, B., Kimbel, W. H., Seyoum, C., Campisano, C. J., DiMaggio, E. N., Rowan, J., Braun, D. R., Arrowsmith, J. R., \& Reed, K. E. (2012).

Early Homo at 2.8 Ma from Ledi-Geraru, Afar, Ethiopia. Science, 347, 1352-1354.

Yorzinski, J. L., Penkunas, M. J., Platt, M. L., \& Coss, R. G. (2014). Dangerous animals capture and maintain attention in humans. Evolutionary Psychology, 12, 534-548. 